ISSN 1392-3196 / e-ISSN 2335-8947

Zemdirbyste-Agriculture, vol. 101, No. 4 (2014), p. 437-444

DOI 10.13080/z-a.2014.101.056

\title{
Measurements of chlorophyll fluorescence in different leaf positions may detect nitrogen deficiency in wheat
}

\author{
Marek ŽIVČÁK ${ }^{1}$, Katarína OLŠOVSKÁ ${ }^{1}$, Pavol SLAMKA ${ }^{1}$, Jana GALAMBOŠOVÁ ${ }^{1}$, \\ Vladimír RATAJ ${ }^{1}$, Hong-Bo SHAO ${ }^{2,3}$, Hazem M. KALAJI ${ }^{4}$, Marián BRESTIČ ${ }^{1}$ \\ 'Slovak University of Agriculture \\ Tr. A. Hlinku 2, 94976 Nitra, Slovakia \\ E-mail: marian.brestic@uniag.sk
}

${ }^{2}$ Key Laboratory of Coastal Biology and Bioresources Utilization, Yantai Institute of Coastal Zone Research, Chinese Academy of Sciences 17 Chunhui, 264003 Yantai, China

${ }^{3}$ Jiangsu Academy of Agricultural Sciences

50 Zhongling, 210014 Nanjing, China

${ }^{4}$ Warsaw University of Life Sciences

Nowoursynowska 159, 02776 Warsaw, Poland

\begin{abstract}
Nitrogen deficiency strongly influences crop photosynthetic performance and biomass production. In this study, we applied rapid, non-invasive records of chlorophyll $a$ fluorescence kinetics for evaluation of wheat (Triticum aestivum L.) leaf photosynthetic performance. Plants were grown during the whole season in big pots filled with the soil substrate and they were supplied by different doses of nitrogen nutrition. The plant nitrogen and leaf chlorophyll content as well as the plant aboveground biomass were analyzed after chlorophyll fluorescence records in three growth stages. Our results confirmed that the maximum quantum yield of photochemistry frequently used in previous studies was almost insensitive to nitrogen treatment, if measured in young, non-senescent leaves. On the contrary, the performance index was much more responsive. The performance index values derived from parallel measurements in the youngest and third leaf from the top were used to calculate performance index leaf ratio, which correlated well with the plant nitrogen content. Moreover, this parameter was not sensitive to midday depression, which significantly affected the values of other chlorophyll fluorescence parameters. Although the optimum performance index leaf ratio values decreased continuously in the second part of the growing season, the optimum and critical values for each growth stage can be easily identified. Thus, we suggest performance index leaf ratio as the simple parameter for the rapid evaluation of the wheat photosynthetic performance and an early indicator of insufficient nutrition level. Unlike some other approaches, suggested method seems to be useful also in conditions of a moderate nutrient deficiency.
\end{abstract}

Key words: JIP-test, non-invasive methods, performance index, photosynthesis, plant diagnostics.

\section{Introduction}

Nitrogen fertilization is one of the most important crop management techniques for production of field crops (Janušauskaite, 2013), especially in conditions affected by adverse environmental factors (Sincik et al., 2013). Nitrogen nutrition influences the plant photosynthetic capacity through the decrease of synthesis of several key photosynthetic enzymes, especially of Rubisco (ribulose-1,5-bisphosphate carboxylase/oxygenase), thus affecting the carbon assimilation, and subsequently also the photochemical processes in thylakoid membranes (Harbinson et al., 1990). Therefore, the thylakoid membrane structures are adjusted to maintain high efficiency in the conversion of energy and to avoid the over-reduction of photosynthetic electron chain in conditions with different nitrogen supply, which can be easily identified using proper analytical methods $(\mathrm{Lu}$ et al., 2001).

The optical measurements based on reflectance or absorbance changes of leaf chlorophyll content have been often applied to characterize the status of the photosynthetic apparatus; however, they contain no information on the photosynthetic activity (Castro et al., 2011). On the other hand, the various methods based on records of chlorophyll fluorescence were shown to be reliable, non-invasive, powerful and simple tools for assessment of photosynthetic electron transport and related photosynthetic processes (Kalaji et al., 2012). Although the basic chlorophyll fluorescence parameters 
such as basal fluorescence $\left(\mathrm{F}_{0}\right)$, maximum fluorescence $\left(\mathrm{F}_{\mathrm{m}}\right)$ or the maximum quantum yield of photochemistry $\left(\mathrm{F}_{\mathrm{v}} / \mathrm{F}_{\mathrm{m}}\right)$, contain valuable information on the status of photosynthetic apparatus (Holá et al., 2010; Janušauskaitė et al., 2011), these parameters are non-specific and often insensitive to many environmental effects (Lawlor, Cornic, 2002; Baker, 2008; Brestic et al., 2012). Much more useful and also generally accepted are parameters obtained by the saturation pulse method in light adapted leaves in steady-state conditions (Baker, 2008); the measurements are, however, time consuming, more suitable for basic research than for practical applications in field conditions. More recently, the non-invasive analysis of polyphasic fast chlorophyll transient has been introduced for rapid evaluation of the photosynthetic function in a high number of field grown plants (Strasser et al., 2000; Stirbet, Govindjee, 2011). The method is based on high-frequency record of chlorophyll fluorescence emitted by dark adapted leaf during short (usually one second lasting) pulse of strong actinic light by fluorimeter. The shape of fluorescence curve reflects the photochemical efficiency of the photosynthetic apparatus and it provides valuable information on the functional and structural attributes of components involved in photosynthetic electron transport, mainly photosystem II (PSII). The fluorescence rise during the first second of illumination shows a sequence of phases (labelled as $\mathrm{O}, \mathrm{K}, \mathrm{J}, \mathrm{I}, \mathrm{P})$ from the initial $\left(\mathrm{F}_{0}\right)$ to the maximal $\left(\mathrm{F}_{\mathrm{m}}\right)$ fluorescence value. The mathematical model of the polyphasic transient was developed and named as JIPtest (Strasser, Strasser, 1995). It enables calculation of specific biophysical parameters, quantum yields and probabilities characterizing structure and function of PSII; moreover, it provides also some integrative parameters. Strasser et al. (2000) introduced the performance index $\left(\mathrm{PI}_{\mathrm{ABS}}\right)$ as the product of three independent parameters, combining structural and functional criteria: density of reaction centres, the quantum efficiency of primary photochemistry and conversion of excitation energy in electron transport. This parameter was found to be much more sensitive to environmental effects than commonly used parameter $\mathrm{F}_{\mathrm{v}} / \mathrm{F}_{\mathrm{m}}$ (Zivcak et al., 2008) and it was shown to be well correlated with photosynthetic capacity measured as $\mathrm{CO}_{2}$ assimilation (Ripley et al., 2004).

The JIP-test analyses were applied several times in studies dealing with nitrogen deficiency in plants and the effect of poor nitrogen supply on PSII has been recently well described (Lu et al., 2001; Redillas et al., 2011; Li et al., 2012). These papers have shown that the rapid fluorescence analysis can be useful for assessing the physiological effects of nitrogen deficiency on plants, but they do not provide a way how to use the method in practical field; our study attempted to address this issue.

In our study, we present the results recorded in winter wheat in three different growth stages and four different nitrogen nutrition levels. More specifically, we also present here the new parameter based on parallel records of chlorophyll fluorescence kinetics in two different leaf positions. The aim of the study is to assess, whether the proposed approach based on fast chlorophyll fluorescence records measured in two leaf levels would be able to identify the level of nitrogen nutrition by quantification of leaf photosynthetic status. Moreover, we will test whether this approach will be more useful than data obtained by a conventional single-leaf approach.

\section{Material and methods}

Cultivation of plants. Pot experiment with winter wheat (cv. 'Akteur') was established on the $22^{\text {nd }}$ of October, 2012 in a vegetation cage of Slovak University of Agriculture in Nitra. Each pot contained 20 $\mathrm{kg}$ of medium heavy brown soil. Owing to the fact that there was sufficient content of mineral nitrogen $\left(\mathrm{N}_{\min }\right)-$ $15 \mathrm{mg} \mathrm{kg}^{-1}$, phosphorus (P) - $90 \mathrm{mg} \mathrm{kg}^{-1}$ and potassium (K) $-224 \mathrm{mg} \mathrm{kg}^{-1}$, in the soil autumn fertilization with mineral fertilizers was not performed. Grain was sown by hand, 32 grains per pot. After wintering, regenerative fertilization of winter wheat with nitrogen was done in spring (18 $8^{\text {th }}$ April, 2013) as follows: treatment $1-0 \mathrm{~g}$ $\mathrm{N}$ per pot $(0 \mathrm{~N})$, treatment $2-0.5 \mathrm{~g} \mathrm{~N}$ per pot $(0.5 \mathrm{~N})$, treatment $3-1.0 \mathrm{~g} \mathrm{~N}$ per pot $(1 \mathrm{~N})$, treatment $4-2.0 \mathrm{~g} \mathrm{~N}$ per pot $(2 \mathrm{~N})$. Nitrogen was applied in the form of liquid fertilizer DAM-390 (UAN-390, Duslo JSC, Slovakia) diluted with water at a ratio of 1:5 (1 part of fertilizer in 5 parts of water). Each treatment was replicated 6 times, i.e. each treatment consisted of 6 pots. During growing period soil moisture in pots was maintained at the level of $50-60 \%$ of full soil water capacity. Aboveground phytomass of plants from one pot in each treatment was sampled three times (3 and 21 May and 7 June) during the vegetation period.

Analysis of total nitrogen. Total nitrogen per dry mass (DM) unit in wheat leaves and whole aboveground phytomass was analyzed in dry mass of bulked samples from 15 plants (after drying at $60^{\circ} \mathrm{C}$ ). The content of total nitrogen (in $\mathrm{mg} \mathrm{g}^{-1}$ of DM) was analyzed using the standard Kjeldahl method. The presented data represent the average value of two parallel samples.

Determination of chlorophyll content. Segments of leaves of sun and shade plants were homogenized using sea sand, magnesium carbonate $\left(\mathrm{MgCO}_{3}\right)$ and $100 \%$ acetone and then extracted with $80 \%$ acetone. After 2-minute centrifugation at $2.500 \mathrm{rpm}$, the absorbance of the solution was measured, by a spectrophotometer (Jenway, UK) at 647 and $663 \mathrm{~nm}$, with correction for scattering at $750 \mathrm{~nm}$. The concentrations of total chlorophyll per leaf area unit were determined, using the equation of Lichtenthaler (1987):

$$
\text { total } \mathrm{Chl}=\left(7.15 \times \mathrm{A}_{663}+18.71 \times \mathrm{A}_{647}\right) \times \mathrm{D} \quad(1),
$$

where the concentrations of the pigments are calculated in $\mathrm{mg} \mathrm{dm}{ }^{-3} ; \mathrm{A}_{\mathrm{n}}$ is the absorbance at a given wavelength (n) after correction for scattering at $750 \mathrm{~nm}$, $\mathrm{D}$ - the optical thickness of the cuvette; results were also recalculated in $\mathrm{mg} \mathrm{m}^{-2}$ using the volume of solution and the area of leaf segments.

Chlorophyll fluorescence measurements. Chlorophyll a fluorescence measurements were performed using the Handy-PEA Continuous Excitation 
Plant Efficiency Analyser (Hansatech Instruments Ltd, UK). The leaf clips were placed on the leaves 20 minutes prior to the measurements to provide dark adaptation. After that, samples were illuminated with continuous red light (wavelength in peak $650 \mathrm{~nm}$, spectral line half-width $22 \mathrm{~nm}$ ). The light was provided by an array of three light-emitting diodes. The light pulse intensity used was $3500 \mu \mathrm{mol} \mathrm{m} \mathrm{m}^{-2} \mathrm{~s}^{-1}$ and the duration of the light pulse was $1 \mathrm{~s}$. The fluorescence signal was recorded with a maximum frequency of 105 points $\mathrm{s}^{-1}$ (each $10 \mu \mathrm{s}$ ) within 0 to $0.3 \mathrm{~ms}$, after which the frequency of recording gradually decreased collecting a total of 118 points within $1 \mathrm{~s}$. Leaf segment measurements were performed in the middle part of a leaf blade, away from the main leaf vein. Chlorophyll a fluorescence transient data were used to calculate the parameters. The $\mathrm{F}_{0}$ level was measured as the fluorescence at $50 \mu \mathrm{s}\left(\mathrm{F}_{50 \mathrm{~s}}\right)$. Maximum quantum efficiency of PSII photochemistry $\left(\mathrm{F}_{\mathrm{v}} / \mathrm{F}_{\mathrm{m}}\right)$ was calculated according to the equation:

$$
\mathrm{F}_{\mathrm{v}} / \mathrm{F}_{\mathrm{m}}=\left(\mathrm{F}_{\mathrm{m}}-\mathrm{F}_{0}\right) / \mathrm{F}_{\mathrm{m}}
$$

Performance index (PI) was calculated as:

$$
\mathrm{PI}_{\mathrm{ABS}}=\frac{1-\left(\mathrm{F}_{0} / \mathrm{F}_{\mathrm{m}}\right)}{\mathrm{M}_{0} / \mathrm{V}_{\mathrm{J}}} \times \frac{\mathrm{F}_{\mathrm{m}}-\mathrm{F}_{0}}{\mathrm{~F}_{0}} \times \frac{1-\mathrm{V}_{\mathrm{J}}}{\mathrm{V}_{\mathrm{J}}}
$$

where $\mathrm{F}_{0}$ means fluorescence intensity at $50 \mu \mathrm{s}$, $\mathrm{F}_{\mathrm{m}}$ represents maximal fluorescence intensity, $\mathrm{V}_{\mathrm{J}}$ is relative variable fluorescence at $2 \mathrm{~ms}$ (J-step), calculated as:

$$
\mathrm{V}_{\mathrm{J}}=\left(\mathrm{F}_{2 \mathrm{~ms}}-\mathrm{F}_{0}\right) /\left(\mathrm{F}_{\mathrm{m}}-\mathrm{F}_{0}\right)
$$

$\mathrm{M}_{0}$ represents the initial slope of fluorescence kinetics, which can be derived as:

$$
\mathrm{M}_{0}=4\left(\mathrm{~F}_{300 \mu \mathrm{s}}-\mathrm{F}_{0}\right) /\left(\mathrm{F}_{\mathrm{m}}-\mathrm{F}_{0}\right)
$$

Chlorophyll fluorescence measurements were done in three cycles: in the growth stages of tillering, stem elongation and before anthesis. Measurements were done always on the newest, fully developed leaf (Leaf 1) and on the third leaf from the top (Leaf 3). Moreover, after anthesis was done also test of parameter stability during hot and sunny day. The fluorescence parameters were calculated separately for Leaf 1 and Leaf 3; moreover, the ratio of $\mathrm{PI}_{\mathrm{ABS}}$ of Leaf 3 and Leaf 1 recorded at the same plant was also calculated and denoted as performance index leaf ratio (PILR), calculated as follows:

$$
\mathrm{PILR}=\mathrm{PI}_{\mathrm{ABS}, \text { Leaf } 3} / \mathrm{PI}_{\mathrm{ABS}, \text { Leaf } 1}
$$

Statistical analysis. The reported data of chlorophyll fluorescence parameters and leaf chlorophyll content represent the mean $+/-$ standard error. Statistical analysis was performed using analysis of variance (ANOVA) followed by Tukey HSD test $(\alpha=0.05)$ by STATISTICA, version 9.0 (Statsoft Inc., USA).

\section{Results and discussion}

Different doses of nitrogen fertilizers led to differences in nitrogen content in leaves as well as to significant differences in production of biomass and some related parameters as shown in Table. Obviously, the highest difference was between treatment without nitrogen supply $(0 \mathrm{~N})$ and other three treatments in nitrogen content as well as in all growth parameters, the differences among $0.5 \mathrm{~N}, 1 \mathrm{~N}$ and $2 \mathrm{~N}$ were lower, but in many cases significant, confirming the positive relationship between nitrogen supply, the leaf chlorophyll content and biomass production. Nonetheless the production of biomass corresponded more to the nitrogen supply than the leaf nitrogen content. The graduation of nitrogen doses fully corresponds with the total nitrogen per plant.

In general, chlorophyll fluorescence techniques have been frequently employed in physiological analyses of nitrogen deficiency in plants; however, with the exception of analytic mechanistic studies, most of the papers use the maximum quantum yield of PSII photochemistry $\left(\mathrm{F}_{\mathrm{v}} / \mathrm{F}_{\mathrm{m}}\right)$ as the main and often the only chlorophyll fluorescence parameter. It is because the measurements of $\mathrm{F}_{0}$ and $\mathrm{F}_{\mathrm{m}}$ are very simple and very fast; moreover, the results can be simply interpreted, as any deeper increase below 0.80 indicates the negative influence of observed factor on photosynthetic apparatus (Brestic, Zivcak, 2013). However, it is well known that $\mathrm{F}_{\mathrm{v}} / \mathrm{F}_{\mathrm{m}}$ is insensitive to many factors that negatively affect plant photosynthesis, such as drought (Zivcak et al., 2008). In plants exposed to nitrogen deficiency lower values of $\mathrm{F}_{\mathrm{v}} / \mathrm{F}_{\mathrm{m}}$ were often found (Guidi et al., 1997; Janušauskaite, Feiziene, 2012). However, our results indicate, that in the youngest, fully developed leaf there is no decrease of $\mathrm{F}_{\mathrm{v}} / \mathrm{F}_{\mathrm{m}}$ values due to nitrogen deficiency (Table).

A different trend was found in the $\mathrm{PI}_{\mathrm{ABS}}$ where the significantly lower values were found in plants poorly supplied with nitrogen (Table). Although the $\mathrm{F}_{\mathrm{v}} / \mathrm{F}_{\mathrm{m}}$ is contained in the formula for calculation of PI, it is supplemented by other components of PSII structure and function related to photosynthetic electron transport (Strasser et al., 2000). More specifically, the decrease of $\mathrm{PI}_{\mathrm{ABS}}$ was mainly due to loss of the density of reaction centres (Lu et al., 2001; Dudeja, Chaudhary, 2005). Similar results were observed in soybean (van Heerden et al., 2004) and maize (Li et al., 2012). In our experiments, the values of $\mathrm{PI}_{\mathrm{ABS}}$ in $0 \mathrm{~N}$ treatment were significantly lower at all three growth stages (Table). It corresponds with the lowest leaf nitrogen and chlorophyll content as well as with low production of biomass. However, the difference between $1 \mathrm{~N}$ and $2 \mathrm{~N}$ were mostly insignificant. Moreover, the $\mathrm{PI}_{\mathrm{ABS}}$ values in plants well supplied with nitrogen were lower at stem elongation than in the other two growth stages.

One of the most typical responses to low nitrogen supply is the N-redistribution from older leaves into youngest growing parts (Hocking, 1994). This, in fact, influences the results of photosynthetic measurements in N-deficient plants in two ways: (i) the moderate nitrogen deficiency will have only minor effects at the level of the top leaf, as it is sufficiently supplied by redistributed nitrogen, and (ii) the photosynthetic capacity of lower leaf positions could be strongly reduced. It is even more complicated in later developmental stages of cereals, as after emergence of the head the nitrogen can be re-distributed also from leaves into the spike, as disassembly of photosynthetic apparatus under stress 
Table. Plant nitrogen, leaf chlorophyll content and chlorophyll fluorescence parameters recorded at three growth stages of winter wheat

\begin{tabular}{|c|c|c|c|c|c|c|c|c|c|c|c|c|}
\hline \multirow{2}{*}{$\begin{array}{c}\text { Growth stage } \\
\mathrm{N} \mathrm{dose} \\
\text { g pot }^{-1}\end{array}$} & \multicolumn{4}{|c|}{$\begin{array}{c}\text { Tillering } \\
\text { (BBCH 25-29) }\end{array}$} & \multicolumn{4}{|c|}{$\begin{array}{l}\text { Stem elongation } \\
\text { (BBCH 35-39) }\end{array}$} & \multicolumn{4}{|c|}{$\begin{array}{l}\text { Pre-anthesis } \\
(\mathrm{BBCH} 55-60)\end{array}$} \\
\hline & 0 & 0.5 & 1 & 2 & 0 & 0.5 & 1 & 2 & 0 & 0.5 & 1 & 2 \\
\hline $\begin{array}{l}\text { Plant } \mathrm{N} \text { content } \\
\mathrm{mg} \mathrm{g}^{-1}\end{array}$ & 24.0 & 38.6 & 38.0 & 43.1 & 13.1 & 25.0 & 28.9 & 27.8 & 10.5 & 14.4 & 20.5 & 26.6 \\
\hline $\begin{array}{c}\text { Total N per plant } \\
\text { mg }\end{array}$ & 8.7 & 21.9 & 28.4 & 37.2 & 7.6 & 27.2 & 34.4 & 43.1 & 5.5 & 28.5 & 43.8 & 73.6 \\
\hline $\begin{array}{l}\text { Plant aboveground } \\
\text { biomass } g\end{array}$ & 0.36 & 0.57 & 0.75 & 0.86 & 0.58 & 1.09 & 1.19 & 1.55 & 0.52 & 1.98 & 2.14 & 2.77 \\
\hline $\begin{array}{l}\text { Total chlorophyll* } \\
\mathrm{mg} \mathrm{m}^{-2}\end{array}$ & $172.8 \mathrm{a}$ & $381.9 \mathrm{bc}$ & $457.7 \mathrm{c}$ & $433.8 \mathrm{c}$ & $233.5 \mathrm{a}$ & $497.7 \mathrm{bc}$ & $596.8 \mathrm{c}$ & $576.4 \mathrm{c}$ & $182.0 \mathrm{a}$ & $361.8 \mathrm{~b}$ & $517.3 \mathrm{c}$ & $619.6 \mathrm{~d}$ \\
\hline $\mathrm{F}_{\mathrm{v}} / \mathrm{F}_{\mathrm{m}} *$ & $0.83 \mathrm{a}$ & $0.83 \mathrm{a}$ & $0.83 \mathrm{a}$ & $0.83 \mathrm{a}$ & $0.83 \mathrm{a}$ & $0.81 \mathrm{~b}$ & $0.81 \mathrm{~b}$ & $0.80 \mathrm{~b}$ & $0.82 \mathrm{ab}$ & $0.82 \mathrm{ab}$ & $0.83 \mathrm{ab}$ & $0.83 \mathrm{a}$ \\
\hline $\mathrm{PI}_{\mathrm{ABS}} *$ & $13.4 \mathrm{a}$ & $26.8 \mathrm{c}$ & $28.1 \mathrm{~cd}$ & $29.1 \mathrm{~cd}$ & $14.3 \mathrm{a}$ & $21.6 \mathrm{~b}$ & $22.1 \mathrm{~b}$ & $21.0 \mathrm{~b}$ & $11.4 \mathrm{a}$ & $25.6 \mathrm{c}$ & $30.0 \mathrm{de}$ & $31.8 \mathrm{e}$ \\
\hline
\end{tabular}

Note. Small letters indicate statistically homogenous groups (ANOVA, Tukey HSD test, $\alpha=0.05$ ); ${ }^{*}$ - determined in upper, youngest, fully developed leaves.

conditions can be a valuable source of nitrogen for the grain (Vassileva et al., 2012). Therefore, in addition to measurements in the youngest leaf positions, we also measured the third leaf from the top. Instead of assessing two positions separately, we suggest using the ratio of

$\mathrm{PI}_{\mathrm{ABS}}$ measured in top (Leaf 1) and the third leaf (Leaf 3) on the same stem at the same time, which we denoted as PILR (Fig. 1). Although this approach may seem unnecessarily complicated, the advantages of using this parameter are discussed below.
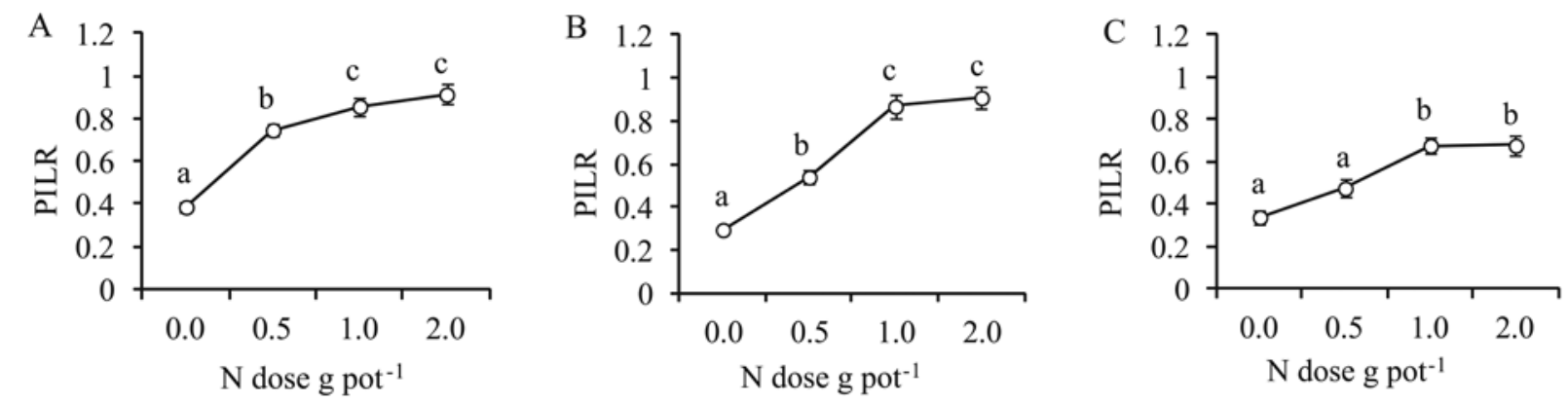

Notes. The results of assessments carried out at three different growth stages are presented: at tillering (A), during stem elongation (B) and before anthesis (C). The points represent the mean values, error bars represent the standard error and the small letters indicate statistically homogenous groups (according to results of ANOVA with post-hoc Tukey test, $\alpha=0.05$ ).

Figure 1. The mean values of performance index leaf ratio (PILR) calculated as ratio between performance index $\left(\mathrm{PI}_{\mathrm{ABS}}\right)$ values recorded in upper leaf (Leaf 1) and third leaf from the top (Leaf 3)

It is obvious, that in addition to $0 \mathrm{~N}$, the PILR was significantly decreased also in $0.5 \mathrm{~N}$; it was not the case of $\mathrm{PI}_{\mathrm{ABS}}$. Another argument for using this parameter
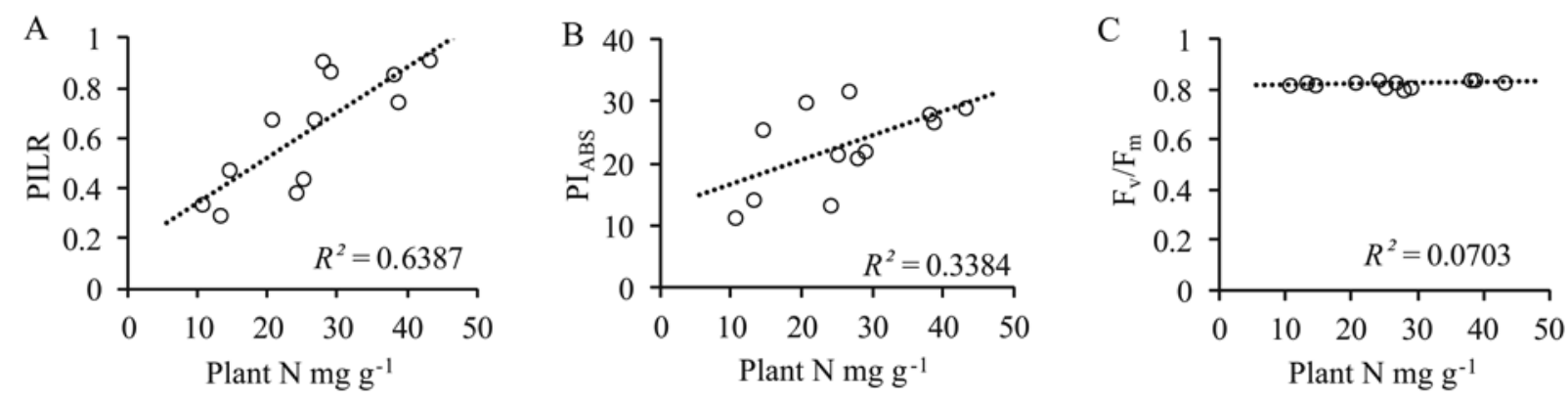

Note. The mean values of parameters obtained in all three growing stages are used in graphs.

Figure 2. Performance index leaf ratio (PILR) (A), performance index $\left(\mathrm{PI}_{\mathrm{ABS}}\right)(\mathrm{B})$ and maximum quantum yield of photochemistry $\left(\mathrm{F}_{\mathrm{v}} / \mathrm{F}_{\mathrm{m}}\right)(\mathrm{C})$ 
While the $\mathrm{F}_{\mathrm{v}} / \mathrm{F}_{\mathrm{m}}$ was not influenced by plant nitrogen supply, the relationship between the plant nitrogen content and mean values of PILR and $\mathrm{PI}_{\mathrm{ABS}}$ were significant. However, we have to admit that the $R^{2}$ values were not too high, mainly due to variation in values recorded at individual growth stages. Moreover, there is an important issue how environmental effects and diurnal changes of external conditions influence the values of chlorophyll fluorescence parameters. For that reason we conducted a special set of measurements during a hot and sunny day at grain filling stage (Fig. 3). Comparison of morning measurements with those done in the afternoon (after plants were exposed for several hours to high light and high temperature) clearly indicates the midday depression well-evident in $\mathrm{PI}_{\mathrm{ABS}}$ values as well as in $\mathrm{F}_{\mathrm{v}} / \mathrm{F}_{\mathrm{m}}$ values (Fig. $3 \mathrm{~B}$ and $\mathrm{C}$ ). Both parameters decreased significantly as the result of photoinhibition supported by high temperature conditions. High light conditions lead to decrease of all of the three components included in $\mathrm{PI}_{\mathrm{ABS}}$, including $\mathrm{F}_{\mathrm{v}} / \mathrm{F}_{\mathrm{m}}$, but mostly the number of reaction centres (Zivcak et al. 2014). Therefore, the values recorded in the afternoon represent only half of the values found in the morning. Thus, the artifacts can be easily obtained if the inappropriate experimental design is used (e.g., measuring one genotype/treatment in the morning and another afternoon).

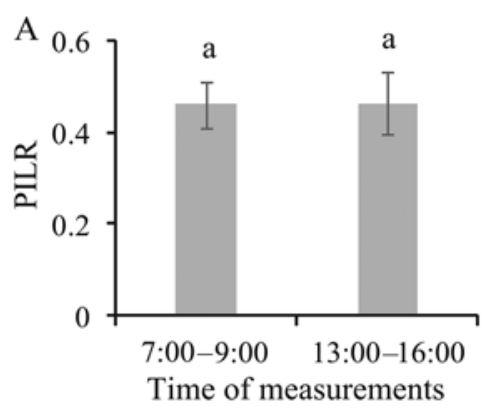

Notes. The records were done during a sunny and hot day (air temperature ranged from $18^{\circ} \mathrm{C}$ at $7: 00$ to $32^{\circ} \mathrm{C}$ at $16: 00$ ). Measurements for assessment of diurnal changes were done in plants with optimum nitrogen nutrition $(1 \mathrm{~N})$ after anthesis $(\mathrm{BBCH} 70-75)$. The columns represent the mean values; error bars represent the standard error, and the small letters indicate statistically homogenous groups (according to results of ANOVA with post-hoc Tukey test, $\alpha=0.05$ ). $\mathrm{PI}_{\mathrm{ABS}}$ and $\mathrm{F}_{\mathrm{v}} / \mathrm{F}_{\mathrm{m}}$ were measured in upper leaves.

Figure 3. Values of performance index leaf ratio (PILR) (A), performance index $\left(\mathrm{PI}_{\mathrm{ABS}}\right)(\mathrm{B})$ and maximum quantum yield of photochemistry $\left(\mathrm{F}_{\mathrm{v}} / \mathrm{F}_{\mathrm{m}}\right)(\mathrm{C})$ measured between 7:00-9:00 in the morning and between 13:00-16:00 in the afternoon

On the contrary, the mean values of PILR parameter were not affected by midday depression, probably due to similar environmental effects in both leaf positions used in calculation of PILR ratio. Therefore, we suggest using this parameter as a more reliable and easily interpretable parameter directly associated with the effect of nutrient remobilization, which stands out in conditions of nitrogen deficiency. It is, however, obvious that it is not possible to generalize the results and take only one optimum PILR level valid for all growing season. A more appropriate way is to define optimum (and/or critical) PILR value for each growth stage. Plotting of our results suggests that while in the first part of the growing season the PILR values were almost constant, starting with the appearance of the spike, the PILR level continuously decreased (Fig. 4). It is in accordance with the fact mentioned above that the spike assumes gradually the function of the main nitrogen sink instead of upper leaves (Vassileva et al., 2012). Interestingly, the PILR values in $\mathrm{N}$-deficient plants were almost stable.

From a practical point of view, the values of PILR between optimum-N and zero-N curves at any growth stage indicate partial nutrient (the most probably nitrogen) deficiency (Fig. 4). As the measurements are really very quick (one record takes only one second and parallel measurements in one plant take only a few seconds, providing immediately useful data for calculation of PILR parameter), we believe this approach is very useful and reliable, especially at early growth stages, when the additional nutrition might be efficiently applied.

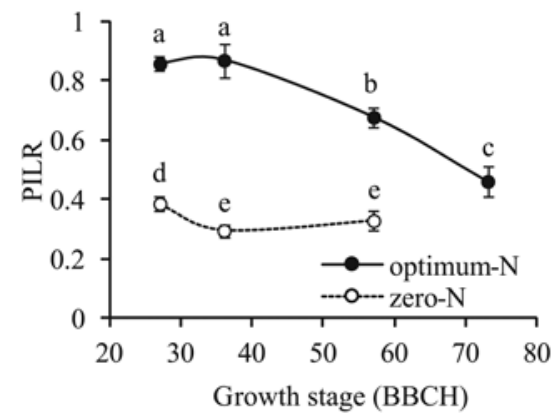

Note. In N-deficient plants, the third leaf was not present (dry) at the last growth stage (after anthesis), therefore PILR could not be calculated.

Figure 4. Values of performance index leaf ratio (PILR) at four growth stages across the growing season in optimally fertilized plants (full symbols) and in plants without nitrogen supply (empty symbols)

To be precise, the decrease in single chlorophyll fluorescence parameter (or any other parameter based on optical analyses) cannot be used as a specific symptom of nitrogen nutrition; they only express the decrease 
of photosynthetic capacity due to lack of nitrogen; the same decrease could be caused by many other factors. Moreover, in natural conditions, the nitrogen insufficiency may occur together with other stress factors, including deficiency of other nutrients. Anyway, the stresses which acts more-or-less equally at any leaf level will affect the PILR parameter less than other parameters. Unlike the other nondestructive parameters, the PILR parameter reflects primarily the effect of redistribution, which is typical mostly for nitrogen. In part this may be complicated by the fact that the redistribution may occur also in a few other nutrients (e.g., magnesium). Fortunately, several studies have indicated the specific PSII-related effects reflected in changes of specific parameters derived from fast chlorophyll fluorescence records (Jiang et al., 2003; Husted et al., 2009; Kalaji et al., 2014). Thus, the contribution of other nutrients to redistribution-related changes in photosynthetic function can be easily detected without the need for any additional measurements. Anyway, the method needs to be further tested and improved to be sufficiently precise and reliable for practical use.

\section{Conclusions}

1. Presented results indicate that the parameters derived from rapid and non-invasive chlorophyll fluorescence records may be used for assessment of leaf photosynthetic function affected by insufficient nitrogen supply.

2. The approach based on parallel measurements in two leaves on the same stem enables calculation of the performance index leaf ratio (PILR), as a useful parameter detecting the loss of photosynthetic capacity in lower leaf positions due to nitrogen remobilization, which is directly related to the level of nitrogen deficiency.

3. The PILR parameter was shown to be insensitive to changes in external conditions during measurements, making this parameter more reliable.

4. The optimum and critical PILR levels can be defined for each growth stage, which can serve for evaluation of the nutrition sufficiency/deficit during whole growing season. Thus, the presented method, including PILR, seems to be useful for practical applications, including field trials.

\section{Acknowledgements}

This work was supported by the European Community under the project No. 26220220180 Construction of the "AgroBioTech" Research Centre, as well as by national grants APVV-0197-10 and APVV0661-10.

Received 05032014

Accepted 22092014

\section{References}

Baker N. R. 2008. Chlorophyll fluorescence: a probe of photosynthesis in vivo. Annual Review in Plant Biology, 59: $89-113$

http://dx.doi.org/10.1146/annurev.arplant.59.032607.092759

Brestic M., Zivcak M. 2013. PSII fluorescence techniques for measurement of drought and high temperature stress signal in crop plants: protocols and applications. Rout G. R., Das A. B. (eds.). Molecular Stress Physiology of Plants, p. $87-131$

Brestic M., Zivcak M., Kalaji H. M., Allakhverdiev S. I., Carpentier R. 2012. Photosystem II thermo-stability in situ: environmentally induced acclimation and genotypespecific reactions in Triticum aestivum L. Plant Physiology and Biochemistry, 57: 93-105 http://dx.doi.org/10.1016/j.plaphy.2012.05.012

Castro F. A., Campostrini E., Torres Netto A., Viana L. H. 2011. Relationship between photochemical efficiency (JIP-test parameters) and portable chlorophyll meter readings in papaya plants. Brazilian Journal of Plant Physiology, 23: 295-304

http://dx.doi.org/10.1590/S1677-04202011000400007

Dudeja S. S., Chaudhary P. 2005. Fast chlorophyll fluorescence transient and nitrogen fixing ability of chickpea nodulation variants. Photosynthetica, 43 (2): 253-259 http://dx.doi.org/10.1007/s11099-005-0041-y

Guidi L., Lorefice G., Pardossi A., Malorgio F., Tognoni F., Soldatini G. F. 1997. Growth and photosynthesis of Lycopersicon esculentum (L.) plants as affected by nitrogen deficiency. Biologia Plantarum, 40: 235-244 http://dx.doi.org/10.1023/A:1001068603778

Harbinson J., Genty B., Baker N. R. 1990. The relationship between $\mathrm{CO}_{2}$ assimilation and electron transport in leaves. Photosynthesis Research, 25: 213-224 http://dx.doi.org/10.1007/BF00033162

Hocking P. J. 1994. Dry-matter production, mineral nutrient concentrations, and nutrient distribution and redistribution in irrigated spring wheat. Journal of Plant Nutrition, 17: 1289-1308 http://dx.doi.org/10.1080/01904169409364807

Holá D., Benešová M., Honnerová J., Hnilička F., Rothová O., Kočová M., Hniličková H. 2010. The evaluation of photosynthetic parameters in maize inbred lines subjected to water deficiency: can these parameters be used for the prediction of performance of hybrid progeny? Photosynthetica, 48: 545-558 http://dx.doi.org/10.1007/s11099-010-0072-x

Husted S., Laursen K. H., Hebbern C. A., Schmidt S. B., Pedas P., Haldrup A., Jensen P. E. 2009. Manganese deficiency leads to genotype-specific changes in fluorescence induction kinetics and state transitions. Plant Physiology, 150: 825-833

http://dx.doi.org/10.1104/pp.108.134601

Janušauskaite D. 2013. Spring triticale yield formation and nitrogen use efficiency as affected by nitrogen rate and its splitting. Zemdirbyste-Agriculture, 100 (4): 383-392 http://dx.doi.org/10.13080/z-a.2013.100.049

Janušauskaite D., Feiziene D. 2012. Chlorophyll fluorescence characteristics throughout spring triticale development stages as affected by fertilization. Acta Agriculturae Scandinavica, Section B: Soil and Plant Science, 62 (1): 7-15 http://dx.doi.org/10.1080/09064710.2011.560122 
Janušauskaitė D., Auškalnienè O., Pšibišauskienė G. 2011. Evaluation of chlorophyll fluorescence in different densities of spring barley. Acta Physiologiae Plantarum, 33: $2159-2167$

http://dx.doi.org/10.1007/s11738-011-0755-3

Jiang C. D., Gao H. Y., Zou, Q. 2003. Changes of donor and acceptor side in photosystem 2 complex induced by iron deficiency in attached soybean and maize leaves. Photosynthetica, 41: 267-271 http://dx.doi.org/10.1023/B:PHOT.0000011960.95482.91

Kalaji M. H., Goltsev V., Bosa K., Allakhverdiev S. I., Strasser R. J. 2012. Experimental in vivo measurements of light emission in plants: a perspective dedicated to David Walker. Photosynthesis Research, 114: 69-96 http://dx.doi.org/10.1007/s11120-012-9780-3

Kalaji H. M., Oukarroum A., Alexandrov V., Kouzmanova M., Brestic M., Zivcak M., Goltsev V. 2014. Identification of nutrient deficiency in maize and tomato plants by in vivo chlorophyll a fluorescence measurements. Plant Physiology and Biochemistry, 81: 16-25 http://dx.doi.org/10.1016/j.plaphy.2014.03.029

Lawlor D. W., Cornic G. 2002. Photosynthetic carbon assimilation and associated metabolism in relation to water deficits in higher plants. Plant, Cell and Environment, 25: 275-294 http://dx.doi.org/10.1046/j.0016-8025.2001.00814.x

Li G., Zhang Z. S., Gao H. Y., Liu P., Dong S. T., Zhang J. W., Zhao B. 2012. Effects of nitrogen on photosynthetic characteristics of leaves from two different stay-green corn (Zea mays L.) varieties at the grain-filling stage. Canadian Journal of Plant Sciences, 92: 671-680 http://dx.doi.org/10.4141/cjps2012-039

Lichtenthaler H. L. 1987. Chlorophyll and carotenoids: pigments of photosynthetic biomembranes. Methods in Enzymology, 148: 350-382 http://dx.doi.org/10.1016/0076-6879(87)48036-1

Lu C., Zhang J., Zhang Q., Li L., Kuang T. 2001. Modification of photosystem II photochemistry in nitrogen deficient maize and wheat plants. Journal of Plant Physiology, 158: $1423-1430$ http://dx.doi.org/10.1078/0176-1617-00501

Redillas M. C. F. R., Jeong J. S., Strasser R. J., Kim Y. S., Kim J. K. 2011. JIP analysis on rice (Oryza sativa cv. Nipponbare) grown under limited nitrogen conditions. Journal of Korean Society for Applied Biology and Chemistry, 54: 827-832 http://dx.doi.org/10.1007/BF03253169

Ripley B. S., Redfern S. P., Dames J. F. 2004. Quantification of the photosynthetic performance of phosphorus-deficient sorghum by means of chlorophyll-a fluorescence kinetics. South African Journal of Science, 100: 615-618

Sincik M., Goksoy A. T., Dogan R. 2013. Responses of sunflower (Helianthus annuus L.) to irrigation and nitrogen fertilization rates. Zemdirbyste-Agriculture, 100: 151-158 http://dx.doi.org/10.13080/z-a.2013.100.019

Stirbet A., Govindjee. 2011. On the relation between the Kautsky effect (chlorophyll $a$ fluorescence induction) and Photosystem II: basics and applications of the OJIP fluorescence transient. Journal of Photochemistry and Photobiology, B: Biology, 104: 236-257 http://dx.doi.org/10.1016/j.jphotobiol.2010.12.010
Strasser B. J., Strasser R. J. 1995. Measuring fast fluorescence transients to address environmental questions: the JIP-test. Mathis P. (ed.). Photosynthesis: from light to biosphere, p. $977-980$

Strasser R. J., Srivastava A., Tsimilli-Michael M. 2000. The fluorescence transient as a tool to characterize and screen photosynthetic samples. Probing photosynthesis: mechanisms, regulation and adaptation, p. 445-483

van Heerden P. D., Strasser R. J., Krüger G. H. 2004. Reduction of dark chilling stress in $\mathrm{N}_{2}$-fixing soybean by nitrate as indicated by chlorophyll a fluorescence kinetics. Physiologia Plantarum, 121: 239-249 http://dx.doi.org/10.1111/j.0031-9317.2004.0312.x

Vassileva V., Demirevska K., Simova-Stoilova L., Petrova T., Tsenov N., Feller U. 2012. Long-term field drought affects leaf protein pattern and chloroplast ultrastructure of winter wheat in a cultivar-specific manner. Journal of Agronomy and Crop Science, 198: 104-117 http://dx.doi.org/10.1111/j.1439-037X.2011.00492.x

Zivcak M., Brestic M., Olsovska K., Slamka P. 2008. Performance index as a sensitive indicator of water stress in Triticum aestivum. Plant, Soil and Environment, 54: 133-139

Zivcak M., Brestic M., Kalaji M. H., Govindjee. 2014. Photosynthetic responses of sun-and shade-grown barley leaves to high light: is the lower PSII connectivity in shade leaves associated with protection against excess of light? Photosynthesis Research, 119: 339-354 http://dx.doi.org/10.1007/s11120-014-9969-8 
ISSN 1392-3196 / e-ISSN 2335-8947

Zemdirbyste-Agriculture, vol. 101, No. 4 (2014), p. 437-444

DOI $10.13080 / \mathrm{z}-\mathrm{a} .2014 .101 .056$

\title{
Azoto trūkumo nustatymas kviečiuose matuojant skirtingose pozicijose esančių lapų fluorescenciją
}

\author{
M. Živčák ${ }^{1}$, K. Olšovská ${ }^{1}$, P. Slamka ${ }^{1}$, J. Galambošová ${ }^{1}$, V. Rataj $^{1}$, H.-B. Shao ${ }^{2}$, H. M. Kalaji ${ }^{3}$, \\ M. Brestič ${ }^{1}$ \\ ${ }^{1}$ Slovakijos žemès ūkio universitetas \\ ${ }^{2}$ Kinijos mokslų akademijos Pajūrio zonos mokslinių tyrimų instituto \\ Pagrindinè pajūrio biologijos ir bioresursų naudojimo laboratorija \\ ${ }^{3}$ Varšuvos gyvybės mokslų universitetas, Lenkija
}

\section{Santrauka}

Azoto trūkumas turi didelès įtakos augalų fotosintezei ir biomasès gamybai. Straipsnyje pateikti tyrimų duomenys gauti taikant greitą neinvazinį chlorofilo $a$ fluorescencijos kinetikos metodą, siekiant nustatyti paprastojo kviečio (Triticum aestivum L.) lapų fotosintezès veiklą. Augalai visą sezoną auginti dideliuose vegetaciniuose induose, pripildytuose dirvožemio substrato, ir tręšti skirtingu kiekiu azoto. Azoto kiekis augaluose bei chlorofilo lapuose ir augalų antžeminė biomasė nustatyti po chlorofilo fluorescencijos matavimo, atlikto trimis augalų augimo tarpsniais. Tyrimų duomenys patvirtino, kad maksimalus kvantų našumas, susijęs su fotosintezės intensyvumu ir matuotas jaunuose, be senējimo požymių lapuose, buvo nejautrus tręšimui azotu. Priešingai nei šie rodikliai, aktyvumo indeksas buvo jautresnis. Paraleliniai jauniausių ir trečio nuo viršūnès lapų aktyvumo indekso matavimai buvo panaudoti lapų veiklos indekso - aktyvumo indeksų santykio, kuris koreliuoja su tręšimu azotu - nustatyti. Be to, šis rodiklis nejautrus vidurdienio depresijai, kuri turi įtakos kitiems fotosintezès fluorescencijos parametrams. Nors augalams augant optimalus lapų aktyvumo indekso rodiklis nuolat mažèja, atskirais augimo tarpsniais jo kritinis ir optimalus parametrai nesunkiai nustatomi. Galima teigti, kad lapų aktyvumo santykio indekso nustatymas yra paprastas rodiklis, siekiant greitai įvertinti kviečių fotosintezès aktyvumą ir azoto trūkumą. Skirtingai nei kiti, šis metodas tinka ir vidutiniam maisto medžiagų trūkumui augaluose nustatyti.

Reikšminiai žodžiai: aktyvumo indeksas, augalų diagnostika, fotosintezè, JIP testas, neinvaziniai metodai. 